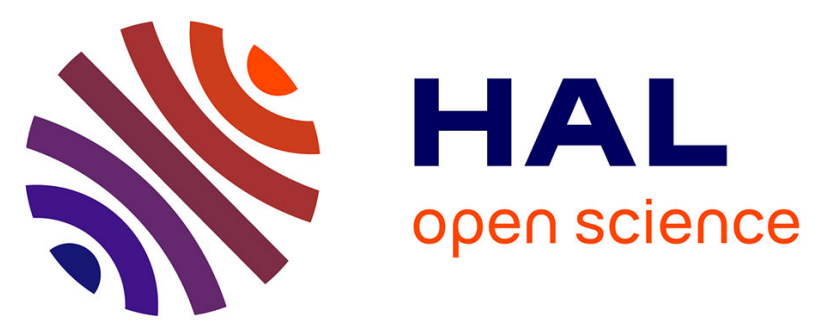

\title{
Electrical structure of the Himalaya of central Nepal: High conductivity around the mid-crustal ramp along the MHT
}

Carole Lemonnier, Guy Marquis, Frédéric Perrier, Jean-Philippe Avouac, Gyani Chitrakar, Basantha Kafle, Som Sapkota, Umesh Gautam, Dilliram Tiwari, Maksim Bano

\section{To cite this version:}

Carole Lemonnier, Guy Marquis, Frédéric Perrier, Jean-Philippe Avouac, Gyani Chitrakar, et al.. Electrical structure of the Himalaya of central Nepal: High conductivity around the mid-crustal ramp along the MHT. Geophysical Research Letters, 1999, 26 (21), pp.3261-3264. 10.1029/1999GL008363 . insu-01298173

\section{HAL Id: insu-01298173 https://hal-insu.archives-ouvertes.fr/insu-01298173}

Submitted on 5 Apr 2016

HAL is a multi-disciplinary open access archive for the deposit and dissemination of scientific research documents, whether they are published or not. The documents may come from teaching and research institutions in France or abroad, or from public or private research centers.
L'archive ouverte pluridisciplinaire HAL, est destinée au dépôt et à la diffusion de documents scientifiques de niveau recherche, publiés ou non, émanant des établissements d'enseignement et de recherche français ou étrangers, des laboratoires publics ou privés. 


\title{
Electrical structure of the Himalaya of Central Nepal: high conductivity around the mid-crustal ramp along the MHT
}

\author{
Carole Lemonnier', Guy Marquis', Frédéric Perrier², Jean-Philippe Avouac², Gyani \\ Chitrakar $^{3}$, Basantha Kafle ${ }^{3}$, Som Sapkota ${ }^{3}$, Umesh Gautam ${ }^{3}$, Dilliram Tiwari ${ }^{3}$ and \\ Maksim Bano ${ }^{1}$
}

\begin{abstract}
Twelve broadband magnetotelluric (MT) soundings were performed across the Himalaya of Central Nepal in 1996 in order to determine the electrical structure of the crust and its relation to geological structures and active tectonics. The MT impedance tensors were obtained for frequencies between 0.001 and $500 \mathrm{~Hz}$. The 2-D section, derived from joint inversion of TE- and TM mode after RRI and Groom/Bailey decomposition, shows high conductivity in the foreland basin ( $-30 \Omega . \mathrm{m})$ that contrasts with the resistive Indian basement ( $>300 \Omega . \mathrm{m}$ ) and Lesser Himalaya (> 1000

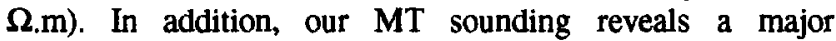
conductive feature beneath the front of the Higher Himalaya, also characterized by intense microseismic activity, and the position of a mid-crustal ramp along the major active thrust fault (MHT). This high conductivity zone probably reflects metamorphic fluids, released during underthrusting of the Indian basement and pervading well connected microcracks induced by interseismic stress build-up, or distributed brittle deformation around the ramp.
\end{abstract}

\section{Introduction}

The structure of the Himalaya and the active tectonic processes at work in the building of the range are now relatively well understood. The Himalayan belt has resulted from underthrusting of the Indian crust beneath southern Tibet. Part of the Indian crust was scraped off during this process, resulting in crustal thickening by tectonic imbrication and in the development of a flexural basin filled with tertiary molasses eroded from the range [e.g., Le Fort, 1975; 1997]. This process is still going on, as suggested by various evidence for active deformation [e.g., Molnar, 1987; Bilham et al., 1997], and has induced metamorphic reactions and crustal melting [e.g., Searle et al., 1997; Henry et al., 1996]. Given that conductivity in the crust depends on fluid content, pore distribution and petrological properties [e.g., Marquis and Hyndman, 1992; Yardley and Valley, 1997], the Himalaya is a particularly appropriate area to investigate the electrical structure of the crust and its bearing on tectonic structures and processes.

The electrical structure of the crust can be retrieved from MT sounding which determines the resistivity structure of the

\footnotetext{
${ }^{1}$ Laboratoire Imagerie Tectonique, EOST, CNRS UMR 7516,

Strasbourg, France

${ }^{2}$ DASE/LDG, Bruyères-Le-Châtel, France

${ }^{3}$ Department of Mines and Geology, Kathmandu, Nepal
}

Copyright 1999 by the American Geophysical Union.

Paper number 1999GL008363.

0094-8276/99/1999GL008363\$05.00 earth by measuring the Earth's natural magnetic and electric fields' time variations. We report here the first application of this technique (MT method) across the Himalaya of Central Nepal. This study extends the MT experiment carried out in southern Tibet that has revealed a zone of high electrical conductivity in the middle crust probably associated with partial melting [Chen et al., 1996; Pham et al., 1986]. In this paper, we first describe the structural setting, the data set, and the processing. We then discuss the results of the 2-D inversion in view of our current understanding of crustal structures and processes.

\section{Structural setting and data acquisition}

Our study consists of 12 soundings from the Gangetic plain to the Higher Himalaya (Figure 1), crossing the various geological units along a line trending $\mathrm{N} 20^{\circ} \mathrm{E}$ which is the direction approximately perpendicular to the regional strike. Three main domains are generally defined (Figure 2). The Higher Himalaya units consist of amphibolite-grade schist and gneiss intruded by leuco-granitic plutons. These units are bounded to the south by the Main Central Thrust (MCT) fault which roughly follows the belt front of the Higher Himalaya [Le Fort, 1975]. The Lesser Himalaya forms the footwall of the MCT south of the Higher Himalaya. It consists mainly of Precambrian to Paleozoic intensely deformed metasediments and is bounded to the south by the Main Boundary Thrust (MBT) [e.g., Gansser, 1964]. Further south, the sub-Himalaya consists of Tertiary molasse sequences involved in thinskinned tectonics induced by thrusting of the Himalaya over the Indian basement in the Siwalik Hills [Gansser, 1964].

Active tectonics is considered to take place on a single fault (Figure 2) that reaches the surface along the Main Frontal Thrust (MFT), flattens beneath the Lesser Himalaya and roots along a ramp beneath the Higher Himalaya [Molnar, 1987; Schelling and Arita, 1991; Pandey et al., 1995; Lave and Avouac, Journal of Geophys. Res., in press]. This fault, that might be called the Main Himalayan Thrust (MHT), connects with a major horizontal reflector under Tibet revealed by the INDEPTH CMP profile [Zhao et al., 1993]. In the interseismic period, the MHT is locked from the surface until the base of the mid-crustal ramp, inducing stress build up and well clustered microseismic activity around the ramp [Bilham et al., 1997; Pandey et al., 1995].

The experiment took place in November and December 1996 using a seven-channel MT acquisition system (SAMTEC2). The magnetic and electric field variations have been measured using induction coils and second generation $\mathrm{Pb} / \mathrm{PbCl}_{2} /$ kaolinite electrodes [Petiau, 1996]. Time series were recorded for 2-3 days at frequency samplings of 15,100 and $1500 \mathrm{~Hz}$ at the 12 sites. 


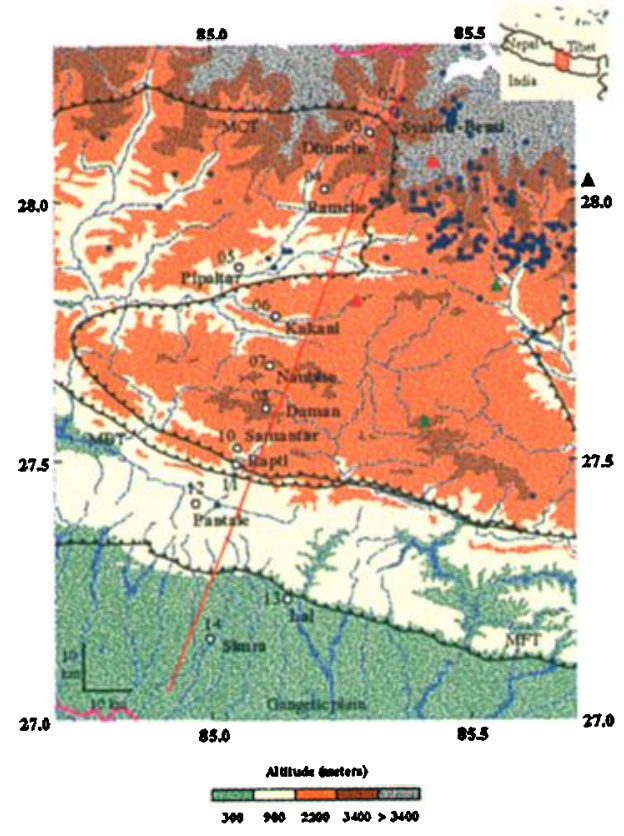

Figure 1. Topographic map of Central Nepal with locations of MT soundings (white dots) on (see insert for location in Nepal). The major faults, MFT (Main Frontal Thrust), MBT (Main Boundary Thrust) and MCT (Main Central Thrust) are also represented. The red line shows the location of section of Figure 2. Epicenters recorded from April to December 1995 by a network of temporary 3-cp stations (red triangles) and permanent 1-cp stations (green triangles) are indicated in blue.

\section{Data analysis and inversion}

The MT transfer functions have been estimated using robust processing [Chave et al., 1987] for frequencies between 0.001 and $500 \mathrm{~Hz}$ (corresponding respectively to penetration depths of approximately 0.5 and $225 \mathrm{~km}$ ). The resulting impedance tensors have been decomposed in order to identify and remove the effects of localized galvanic distortion [Groom and Bailey, 1989]. Figure 3 represents the decomposed apparent resistivities for four sites. Decomposition results from sites within the Gangetic Plain indicate a relatively consistent $1-D$ electrical structure there, the structure is of growing complexity, from 2D in central to
3D in northern Nepal. However, in spite of the complex MCT geometry at the surface (Figure 1), the structure is probably two-dimensional at depth, as indicated from the general trend of structures and linear belt of microseismicity (Figure 1) [Pandey et al., in press].

The data were inverted with the Rapid Relaxation Inversion method (RRI) [Smith and Booker, 1991]. We built 2-D models with a projection along a $\mathrm{N} 20^{\circ} \mathrm{E}$ profile and inverted together TE ( $\mathrm{N}^{\circ} 110 \mathrm{E}$ orientation, current flowing along strike, YX component) and $\mathrm{TM}$ (N20 ${ }^{\circ}$, current flowing across strike, XY component) mode data after decomposition (the resulting strike is close to $20^{\circ}$ ). For 2-D structures, TE is more sensitive to conductivity variations in depth and TM to lateral discontinuities. A joint inversion is useful to obtain a best representation of electrical structure. To test which features of the inversion results are robust, i.e. are resolved regardless of the initial model used in the inversion, we have tried inversions with two different initial models. The first was a model with randomly distributed conductivity and the second a $100 \Omega \mathrm{m}$ half-space. The two final models are practically identical and only the latter will be shown here (Figure 4a).

To illustrate the quality of the fit of the model shown in figure $4 \mathrm{a}$, we have computed the misfit between the synthetic 2-D response and the observed data for both TE and TM modes. The average value between the two modes,

$$
\mathrm{ms}=\left|\log \left(\sqrt{\frac{\rho_{\text {calc.TE }}}{\rho_{\text {obs.TE }}} \cdot \frac{\rho_{\text {calc.TM }}}{\rho_{\text {obs.TM }}}}\right)\right|
$$

is shown for each frequency at each site in the section in Figure 4b. Values near zero (blue) indicate a good fit. Except at the northernmost sites (03-02) and at sites 08 and 05 at low frequencies, the pseudosection shows that the final model fits well the data $(\mathrm{ms}<0.5)$.

\section{Results and discussion}

Variations of conductivity in the crust are generally ascribed to changes in fluid content, pore distribution or petrological properties. Conductive zones are generally thought to reflect well connected conductive phases: brines, melts, or conductive minerals [e.g., Marquis and Hyndman, 1992: Yardley and Valley, 1997]. The strong correlation

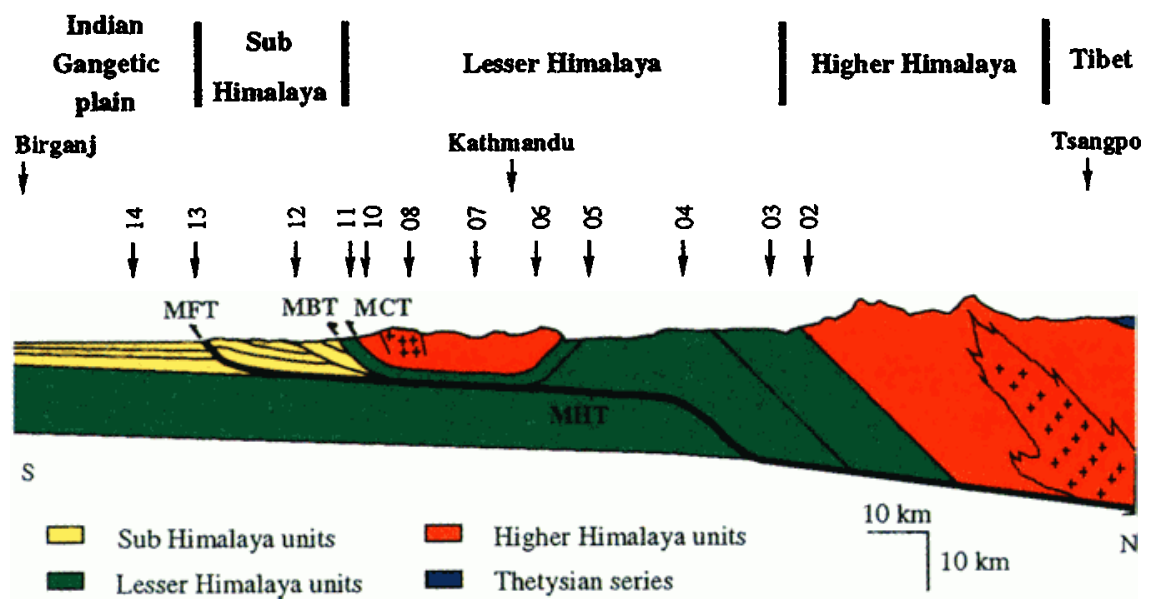

Figure 2. Geological section across the central Himalaya of Nepal (along the line through Birganj and Syabru-Bensi indicated in Figure 1) with MT site locations. Locations of major faults are shown. The thick line indicates the geometry of the main active fault (MHT) as inferred from structural geology and geomorphic evidence of uplift. 

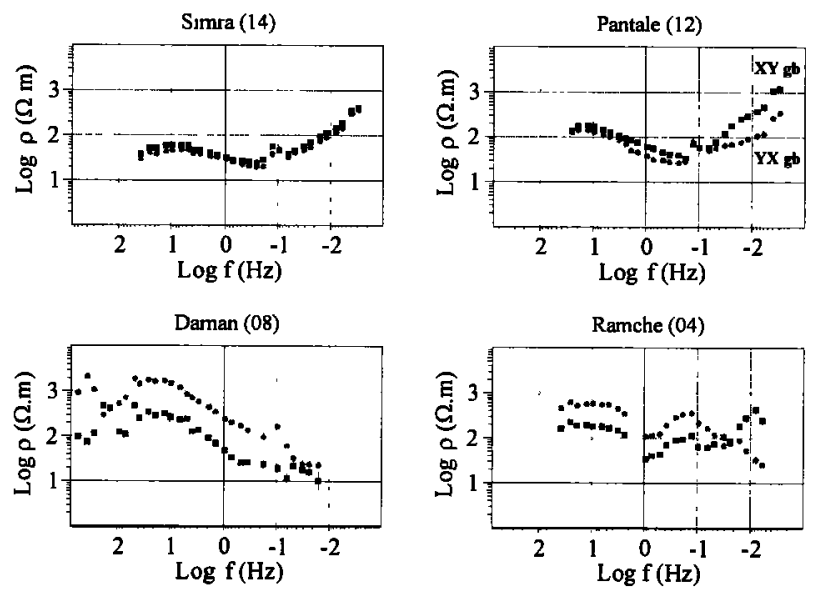

Figure 3. Components $\mathrm{XY}$ and $\mathrm{YX}$ of the decomposed MT transfer functions represented for four sites, Simra (14) and Pantale (12) in the south, Daman (08) in the Kathmandu valley and Ramche (04) in the north.

between the electrical and geological structures (Figure 4a) was therefore expected. The Gangetic foreland is characterized by low resistivities ( $-30 \Omega . \mathrm{m})$ consistent with the presence of molassic sediments (see also Gupta et al. [1994]). The conductive body encompasses sites 14 to 11 and stops at the MBT. It indicates a depth to the Indian basement, that is characterized by higher resistivities (> $300 \Omega . \mathrm{m}$ ) of about $5 \mathrm{~km}$ consistent with that inferred from balanced cross sections across the Siwalik hills along the same section [Schelling et al., 1991] or farther to the east [Lave and Avouac, J. Geophys. Res., in press]. Because of the screening effect of the conducting Siwaliks, the actual resistivity of the Indian crust is not well defined. Note however that the Indian upper crust is less resistive than its lower crust (> $1000 \Omega$.m) as often observed, probably because deep crustal rocks are depleted in fluids [Yardley and Valley, 1997].

North of the MBT, the metamorphic rocks of the Lesser Himalaya and of the overlying klippe are rather resistive (>

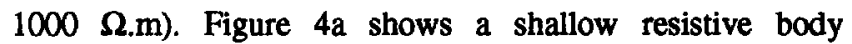
(resistivity of about $2000 \Omega . \mathrm{m}$ ) that might be related to the Ordovician granites that crop out along the southern edge of the Kathmandu klippe around site 08 (Figure 2). It extends to a depth of about $7 \mathrm{~km}$ under the Kathmandu klippe consistent with the depth to the detachment proposed in the structural section of Figure 2. The small conductive body under site 07 is not reliable. The shallow conductive feature under site 05 corresponds to the clay-rich Trisuli river terraces.

The most remarkable electrical feature is probably the 20 $\mathrm{km}$ deep conductor (with resistivities of the order of $30 \Omega . \mathrm{m}$ ), located under site 04 near the boundary between the Lesser and Higher Himalayas. The lateral dimension and the downward extension of the structure are not well determined but the top of this good conductor is well resolved. This conductive zone happens to coincide with the position of the crustal ramp along the MHT (Figure 2). The position of the ramp is constrained from the anticlinal structure of the Lesser Himalaya [Schelling and Arita, 1991] and also from a zone of uplift documented from geomorphic evidence [Molnar, 1987; Lavé and Avouac, J. Geophys. Res., in press]. This geometric asperity along the MHT must induce deformation of the surrounding medium thus favoring fluid circulation, especially in the brittle portion of the crust. An aqueous fluid porosity of about $3 \%$ is sufficient to explain the high conductivity.

Figure $4 \mathrm{a}$ also shows that the conductive zone also coincides with the area of intense microseismic activity that reflects stress build up and increased Coulomb stresses in the interseismic period, as demonstrated from mechanical modelling [Cattin and Avouac, J. Geophys. Res, submitted]. Thus, invoking either interseismic processes or long-term thrusting along the mid-crustal ramp, the conductive zone probably corresponds to an area where deformation should favor connectivity of the conductive phases present in the medium. The most likely conductive phase is fluids, since underthrusting of the Indian crust can ensure continuous recharge of the hanging wall by fluids released during dehydration reactions. Pore pressure build-up due to
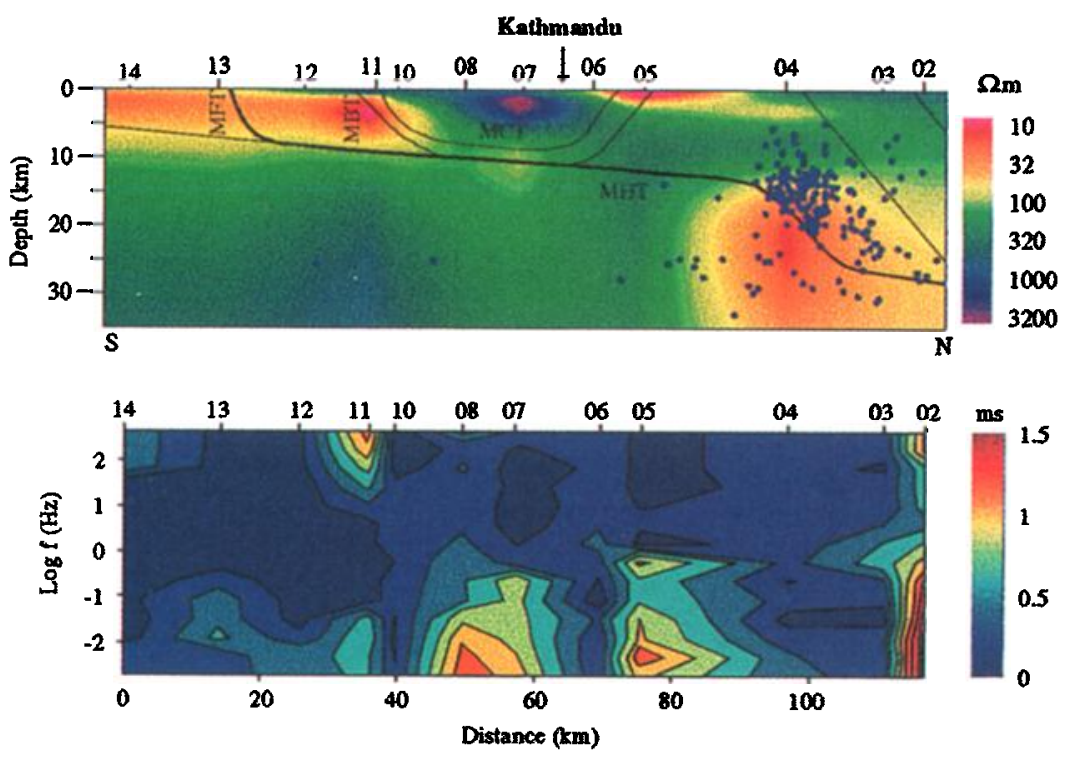

Figure 4. a) $\mathrm{N} 20^{\circ} \mathrm{E}$ cross section of resistivity model derived from the 2-D inversion of MT data. Main Frontal Thrust (MFT), Main Boundary Thrust (MBT), Main Central Thrust (MCT) and Main Himalayan Thrust (MHT) are represented. Hypocenters within $30 \mathrm{~km}$ from the section recorded by the temporary seismic network (Figure 1) are shown in blue. b) Pseudosection illustrating the misfit between the model response and the observed data (see text). Site locations are plotted from south to north. 
metamorphic dehydration may indeed take place over a time span of the order of the interseismic period [Ague et al., 1998]. The presence of fluids may in turn contribute to the clustering in microseismic activity. The conductive anomaly that we observe under the Higher Himalayas is located in the zone where large earthquakes are expected to nucleate [Lavé and Avouac, J. Geophys. Res., in press]. Note that conductive zones in the middle crust have also been observed beneath the epicentral zones of some earthquakes [Gupta et al., 1996; Zhao et al., 1996].

An alternate explanation is that the conductive zone may be related to a concentration of deep fluids trapped under the brittle-ductile transition [Marquis and Hyndman, 1992]. Thermal modeling by Henry et al. [1996] shows that the temperature at the ramp is between 300 and $500^{\circ} \mathrm{C}$, so its upper and lower parts are respectively above and below the brittle-ductile transition (assumed here as $400^{\circ} \mathrm{C}$ ). If this is the case then the conductor should extend northward, but, as mentioned above, the data under sites 03 and 02 can not be used to test this hypothesis.

We therefore contend that the conductive body beneath the front of the higher Himalaya most probably reflects fluids released by metamorphic reaction in the footwall during underthrusting of the Indian crust along the mid-crustal ramp and that percolates upward into the brittle portion of the crust where intense microseismic activity is observed. The conductivity near the ramp may therefore change in the intersismic period, and may possibly allow for the observation of precursory phenomena. However, although changes of shallow rock conductivity with time has been observed to be linked to stress accumulation [Chu et al., 1996], no such observations have been yet reported in the middle crust.

Acknowledgments. We thank M.R. Pandey, R.P. Tandukar and P. Le Fort for support. R. Koirala, B. Tissot and J. Durand have been of great help during the field operations or the preparation of the experiment. Some of the software used in this study was acquired through the Geotools European Consortium. Funding was provided by CNRS/NSU IDYLHIM project and by the cooperation agreement between DASE/LDG and DMG. We also thank the anonymous reviewers for their helpful comments and suggestions.

\section{References}

Ague, J.J., J. Park, and D.M. Rye, Regional metamorphic dehydration and seismic hazard, Geophys. Res. Lett., 25, 42214224, 1998.

Bilham, R., K. Larson, J. Freymuller and Project IDYL-HIM members, Indo-Asian Convergence rates in the Nepal Himalaya, Nature, 386, 61-66, 1997.

Chave, A. D., D. J. Thomson and M. A. Ander, On the Robust Estimation of Power Spectra, Coherences, and Transfer Functions, J. Geophys. Res., 92, 633-648, 1987.

Chen L., J. R. Booker, A. G. Jones, N. Wu, M. J. Unsworth, W. Wei and $H$. Tan, Electrically conductive crust in southern Tibet from in depth MT surveying, Science, 274, 1694-1696, 1996.

Chu, J.J., X. Gui, J. Dai and C. Marone, Geoelectric signals in China and the earthquake generation process, J. Geophys. Res., 101, $13,869-13,882,1996$.

Gansser, A., Geology of the Himalayas, Inter-Science Publisher, New York, N.Y., 289 pp, 1964.
Groom, R.W. and R. C. Bailey, Decomposition of magnetotelluric impedance tensors in the presence of local three-dimensional galvanic distortion, J. Geophys. Res., 94, 1913-1925, 1989.

Gupta, G., S. G. Gokarn and B. P. Singh, Thickness of the Siwalik sediments in the Mohand-Ramnagar region using magnetotelluric studies, Phys. Earth. Planet. Int., 83, 217-224, 1994.

Gupta, H.K., S.V.S. Sarma, T. Harinarayan and G. Virupakshi, Fluids below the hypocentral region of Latur earthquake, India: Geophysical indicators, Geophys. Res. Lett., 23, 1569-1572, 1996.

Henry, P., X. Le Pichon and B. Goffé, Kinematic, thermal and petrological model of the Himalayas: constraints related to metamorphism within the underthrust Indian crust and topographic elevation, Tectonophysics, 273, 31-56, 1996.

Lave, J., and J.P. Avouac, Active folding of abandoned Fluvial Terraces across the Siwalik Hills (Nepal), J. Geophys. Res., in press.

Le Fort. P., Himalayas: the collided range, present knowledge of the continental arc, Am. J. of Sci., 275 A, 1-44, 1975.

Le Fort, P., Evolution of the Himalaya, in "The Tectonic Evolution of Asia", A. Yin and M. Harrison ed., Cambridge University press, 95-109, 1997.

Marquis, G. and R. D. Hyndman, Geophysical support for aqueous fluids in the deep crust: seismic and electrical relationships, Geophys. J. Int., 110, 91-105, 1992.

Molnar, P.. Inversion of profiles of uplift rates for the geometry of dip-slip faults at depth, with examples from the Alps and the Himalaya. Ann. Geophysicae, 5, 663-670, 1987.

Pandey, M. R., R. P. Tandukar, J. P. Avouac, J. Lavé and J. P. Massot, Interseismic strain accumulation on the Himalayan crustal ramp (Nepal), Geophys. Res. Let., 22, 751-754, 1995.

Pandey, M. R., R .P. Tandukar, J. P. Avouac, J. Vergne and T. H. Héritier, Characteristics of seismicity of Nepal and their seismotectonic implications, Journal of Asian Tectonics in press.

Petiau, G., $\mathrm{Pb} / \mathrm{PbCl}_{2}$ Electrodes: second generation, Proceedings of the Workshop "Electrodes", Garchy, April 24-29, 1995 (Edited by G.Clerc, F. Perrier, G. Petiau and M. Menvielle), 49-51, 1996.

Pham, V. N., D. Boyer, P. Therme, X. C. Yuan, L. Li and G. Y. Jin, Partial melting zones in the crust in southern Tibet from magnetotelluric results, Nature, 319, 310-314, 1986.

Schelling, D. and K. Arita, Thrust tectonics, crustal shortening and the structure of the Far Eastern Nepal Himalaya, Tectonics, 10, 851-862, 1991.

Schelling, D.. J. Cater, R. Seago and T.P. Ojha, A balanced crosssection across the central Nepal Siwalik Hills; Hetauda to Amlekhganj, J. Fac. Hokkaido Univ., 23, 1-19, 1991.

Searle, M.P., R.R. Parrish, K.V. Hodges, A. Hurford, M.W. Ayres and M.J. Whitehouse, Shısha Pangma Leucogranite, South Tibetan Himalaya: field relations, geochemistry, Age origin and emplacement, J. Geol.. 105, 295-317, 1997.

Smith, J. T., J. R. Booker, Rapid inversion of two-dimensional magnetotelluric data, J. Geophys. Res., 96, 3905-3922, 1991.

Yardley, B.W.D. and J.W. Valley, The petrologic case for a dry lower crust, J. Geophys. Res., 102 B6, 12,173-12,185, 1997.

Zhao, W., K.D. Nelson and project INDEPTH Team, Deep seismic reflection evidence for continental underthrusting beneath southem Tibet, Nature, 366, 557-559, 1993.

Zhao, D., H. Kanmori, H. Negishi, and D. Weins, Tomography of the source area of the 1995 Kobe earthquake: evidence for fluids at the hypocenter ?, Science, 274, 1891-1894, 1996.

M. Bano, C. Lemonnier, G. Marquis, Laboratoire Imagerie Tectonique, EOST, 5 rue René Descartes, 67084 Strasbourg, France. (e-mail: mbano, clemonnier or gmarquis @ eost.u-strasbg.fr)

J. P. Avouac, F. Perrier, DASE/LDG, 91680 Bruyères-Le-Châtel, France. (e-mail: avouac or perrier@ldg.bruyeres.cea.fr)

G. Chitrakar, U. Gautam, B. Kafle, S. Sapkota, D. Tiwari, Department of Mines and Geology, Kathmandu, Nepal. (e-mail: nscdmg@mos.com.np)

(Received May 18, 1999; revised July 9, 1999; accepted August 6, 1999.) 